\title{
NUP107 wt Allele
}

National Cancer Institute

\section{Source}

National Cancer Institute. NUP107 wt Allele. NCI Thesaurus. Code C101488.

Human NUP107 wild-type allele is located in the vicinity of 12 q15 and is approximately 56 $\mathrm{kb}$ in length. This allele, which encodes nuclear pore complex protein Nup107, plays a role in nuclear transport. 